\title{
Regional Diversification of Potential, Production and Efficiency of Use of Biogas and Biomass in Poland
}

\author{
Grzegorz Ślusarz $^{1}$, Barbara Gołębiewska ${ }^{2, * \mathbb{D}}$, Marek Cierpiał-Wolan ${ }^{1}$, Jarosław Gołębiewski ${ }^{2}$, Dariusz Twaróg ${ }^{3}$ \\ and Sebastian Wójcik 4 (iD
}

1 Institute of Economics and Finance, University of Rzeszów, ul. M. Ćwiklińskiej 2, 35-601 Rzeszów, Poland; gslusarz@ur.edu.pl (G.Ś.); M.Cierpial-Wolan@stat.gov.pl (M.C.-W.)

2 Institute of Economics and Finance, Warsaw University of Life Sciences-SGGW, Nowoursynowska 166, 02-787 Warsaw, Poland; jaroslaw_golebiewski@sggw.edu.pl

3 Statistical Office in Rzeszów, Jana III Sobieskiego 10, 35-001 Rzeszów, Poland; D.Twarog@stat.gov.pl

4 Institute of Mathematics, University of Rzeszów, ul. Pigonia 1, 35-959 Rzeszów, Poland; swojcik@ur.edu.pl

* Correspondence: barbara_golebiewska@sggw.edu.pl; Tel.: +48-22-5934228

Citation: Ślusarz, G.; Gołębiewska, B.; Cierpiał-Wolan, M.; Gołębiewski, J.; Twaróg, D.; Wójcik, S. Regional Diversification of Potential, Production and Efficiency of Use of Biogas and Biomass in Poland. Energies 2021, 14, 742. https:// doi.org/10.3390/en14030742

Academic Editor: Alberto-Jesus Perea-Moreno

Received: 23 December 2020

Accepted: 27 January 2021

Published: 31 January 2021

Publisher's Note: MDPI stays neutral with regard to jurisdictional claims in published maps and institutional affiliations.

\section{Copyright: (c) 2021 by the authors.} Licensee MDPI, Basel, Switzerland. This article is an open access article distributed under the terms and conditions of the Creative Commons Attribution (CC BY) license (https:// creativecommons.org/licenses/by/ $4.0 /)$.

\begin{abstract}
Energy obtained from renewable sources is an important element of the sustainable development strategy of the European Union and its member states. The aim of this research is, therefore, to assess the potential and use of renewable energy sources and their effectiveness from the regional perspective in Poland. The research covered the years 2012 and 2018. The diversification of production and potential of renewable energy sources was defined on the basis of biogas and biomass. Calculations made using the data envelopment analysis (DEA) method showed that, in 2012, only three voivodeships achieved the highest efficiency in terms of the use of biogas and biomass resources; in 2018, this number increased to four. Comparing the effective units in 2012 and 2018 , it can be seen that their efficiency frontier moved upwards by $56 \%$ in terms of biogas and $21 \%$ in terms of to biomass. Despite a large relative increase in the production of heat from biogas by $99 \%$ compared to the production of heat from biomass by $38 \%$, the efficiency frontier for biogas did not change considerably. It was found that the resources of solid biomass are used far more intensively than the resources of biogas. However, in the case of biogas, a significant increase in the utilization of the production potential was observed: from 3.3\% in 2012 to $6.4 \%$ in 2018 , whereas in the same years, the utilization of solid biomass production potential remained at the same level (15.3\% in 2012, $15.4 \%$ in 2018). It was also observed that, at the level of voivodeships, the utilization of biogas and biomass production potential is negatively correlated with the size of this potential. The combined potential of solid biomass and biogas can cover the demand of each of the studied regions in Poland in terms of thermal energy. The coverage ranges from $104 \%$ to $1402 \%$. The results show that when comparing biomass and biogas, the production of both electricity and heat was dominated by solid biomass. Its high share occurred especially in voivodeships characterized by a high share of forest area and a low potential for biogas production (Lubuskie Voivodeship, Zachodniopomorskie Voivodeship).
\end{abstract}

Keywords: biogas; biomass; data envelopment analysis (DEA); efficiency ranking; renewable energy; Poland; regional potential

\section{Introduction}

Due to the development of civilization, more and more energy resources are necessary to satisfy basic social needs as well as production. Lack of integration in resource assessment and policy making leads to inconsistent strategies and inefficient use of resources [1]. Fossil fuels play a dominant role in global energy systems [2], although according to Arığlu et al. [3], renewable energy sources are becoming the fastest growing energy source in the world. As pointed out by Moomaw et al. [4], 85\% of the primary energy used by global economies comes from fossil fuels. However, the share of energy from renewable 
sources in the structure of energy consumption is growing rapidly, especially in Europe. In 2018, the share of energy from fossil fuels in the EU decreased to $70.2 \%$ of total energy [5].

In recent years, more and more attention has been paid to the development and use of energy from renewable sources [6,7]. Moomaw et al. [4] report that renewable energy sources play a role in the provision of energy services in a sustainable manner, and in particular in mitigating climate change. Gielen and his team [8] also note that renewable energy can meet two-thirds of the total global energy demand and contribute, to a large extent, to the reduction in greenhouse gas emissions responsible for climate change.

Activities in the field of production of energy from renewable sources are undertaken in many countries of the world, not only in EU countries, pointing to their importance for the development of rural areas [9-11]. As Lemaire [12] shows, in rural South Africa, small energy companies can play useful roles in supplementing conventional systems.

Renewable energy and energy efficiency are the two main components of sustainable energy systems. Abolhosseini and his team [13] indicate that electricity consumption will constitute an increasing share of global energy demand over the next two decades. Therefore, the development of renewable energy sources is becoming one of the most important challenges in light of the increasingly energy-consuming socio-economic development and the need to reduce the share of fossil, high-emission sources of energy production. This is due to the so-called climate and energy package implemented in EU countries, which assumed a $20 \%$ reduction in greenhouse gas emissions by 2020 compared to 1990 and an increase in the share of renewable energy sources (RESs) in total energy consumption by $20 \%$ [14]. Such a limitation is also reflected in the assumptions of the EU climate and energy policy in the 2030 perspective [15]. For Poland, according to this document, this share accounted for at least $15 \%$ in 2020 [16]. Due to the slow pace of development of renewable energy sources, this goal will require many years of multidirectional activities. These activities should take into account the spatial differentiation of development conditions, and thus the diversified opportunities for the development of renewable energy sources. This task is difficult because the structure of electricity produced in Poland has been dominated by energy produced from high-emission solid fuels for many years. In 2015, hard coal accounted for $46.5 \%$ of these fuels, lignite $32.2 \%$, natural gas 3\%, renewable energy $13.7 \%$, and the remaining $4.6 \%$ [17]. High-emission fossil fuels are a common global problem. They are the cause of more than $70 \%$ of greenhouse gas emissions in the world [18]. Hence, the issue of the development of a low-emission economy and energy generation based on low-emission sources is of particular importance.

Rural areas, along with the agriculture and forestry sectors located within them, have an important role to play in generating renewable energy sources, especially as agricultural land and forests dominate the land use structure in all regions of Poland [19]. This diversification may undoubtedly affect the potential possibilities of producing biomass, which is the largest source of renewable energy, mainly obtained in agriculture [20]. Solid biofuels as well as raw materials for the production of liquid fuels from biomass (biodiesel and bioethanol) and some biogases are produced from biomass [21].

Thus, the agricultural sector may not only be an emitter of greenhouse gases and a consumer of energy, but may also have the potential to generate energy [22,23]. As indicated by Hengeveld et al. [24], an increasing number of local and regional initiatives show a growing interest in decentralized energy production, in which biogas can play a role. Carrosio [25], who studied the evolution of agricultural biogas production in Italy, also believes that in order to achieve a more sustainable development of bioenergy, the existing institutional framework should be reformed by reorganizing subsidies and involving farmers in local projects. It is therefore expected that the amount of biogas produced on agricultural land will increase in the coming years.

This issue receives little recognition in the countries of Central and Eastern Europe and in Poland itself. Such studies have so far been conducted in China [26,27], in Vietnam [28], or in Ukraine [29], but most studies focus mainly on technical or technological issues related to the production of this energy [30-32], while less work is devoted to the spatial 
differentiation of the efficiency of biomass and biogas potential. The issues of the spatial distribution of infrastructure [33,34], the deployment of the renewable energy industry [35], and spatial planning in terms of resource availability and use [36], were addressed, including waste for biogas production $[37,38]$. A spatial analysis of the power density of renewable energy was carried out [39]. Research in the field of solar and wind energy was also often conducted $[40,41]$. Spatial aspects also concern the differences between EU countries [42,43].

Therefore, even if renewables are distributed all over the world, location plays a huge role in deciding which resources to use, not only globally but also locally. In addition, it is important to assess the energy efficiency of different regions, which can help to identify differences in energy efficiency, which can be the basis for improving this efficiency.

The main aim of the research is to look for answers to the fundamental question regarding the potential of and resources required for use of biomass and biogas in Poland and the effectiveness of their use, the calculation of which was carried out using the data envelopment analysis (DEA) method, widely used in the field of environmental and energy economics [44-47].

The analyses highlighted the regions in Poland where the production of biogas and biomass is highly developed and where they constitute the largest share in total energy. Answers were also sought to the question regarding the efficiency of energy production from biomass and biogas in the regions and whether they can achieve energy self-sufficiency based on local resources.

\section{Research Methodology}

The research was carried out at the regional level in Poland. The spatial scope of detailed research covered all voivodeships (regions) of the country. To compare the efficiency of useful heat production by voivodeships, data on the consumption of biogas and biomass from the report on heat from renewable sources of Statistics Poland were used. The adopted approach takes into account those renewable energy sources that can occur throughout the country without major restrictions, can be produced in each region, and are related to agriculture. The data of Local Data Bank of Statistics Poland were also used.

\subsection{Partial Ranking and Hasse Diagram}

The ratio of potential of heat production from biogas to biogas consumption was calculated, as well as a similar indicator for biomass for each voivodeship. If one region dominates another with respect to indicators under comparison, it is easy to determine which region is better. In another case, there is a need to establish a trade-off between indicators to make a comparison. The partial ranking shows only unambiguous comparisons and introduces a partial ordering in the region under comparison. The partial ranking can be visualized with a Hasse diagram with takes a form of graph. In the Hasse diagram, if there is an arrow from one object to another, it means that the first of them is better than the second one in terms of each analyzed variable. The situation when one can move from the first to the second object through a sequence of arrows with the same direction is interpreted in a similar way. If there is no sequence of arrows between objects, such objects are incomparable.

\subsection{Data Envelopment Analysis}

The data envelopment analysis (DEA) method was used to organize the voivodeships in terms of effectiveness, but without indicating the distance between the other voivodeships and the leaders.

The basis of this method is a set of variables that are inputs and a set of variables that are outputs. The DEA method is widely used to study energy efficiency as a total factor energy efficiency evaluation method [48]. DEA belongs to the group of nonparametric methods of linear programming, in which efficiency is defined as the quotient of the weighted sum of effects to the weighted sum of inputs [49]. The DEA allows the 
effectiveness of each Decision-Making Unit (DMU) to be maximized by selecting weights assigned to inputs and effects [50]. This allows for the identification of relatively effective and ineffective units and the measurement of the ineffectiveness of the latter. This approach also makes it possible to compare DMUs with very diverse structures, natures of effects and inputs, and to estimate unobservable technological elements directly from inputs and effects without applying restrictive assumptions about the parameters in the production process [51]. In this method, at least one object always has 100\% efficiency. The efficiency of all the others is compared with the objects with $100 \%$ efficiency; hence, the relative efficiency is obtained.

When presenting the idea of the basic DEA model, it should be noted that $y_{j k}$ $(j=1, \ldots, n)$ stands for effects (outputs) and $x_{i k}(i=1, \ldots, m)$ stands for inputs of $k$-th DMU $(k=1, \ldots, r)$. In DEA, for each fixed DMU (say $\mathrm{t}$ ), a system of weights for inputs $v_{i t}(i=1, \ldots, m)$ and effects $w_{j t}(j=1, \ldots, n)$ must be found that maximizes the following expression

$$
E f_{t}=\frac{\sum_{j}^{n} w_{j t} y_{j t}}{\sum_{i}^{m} v_{i t} x_{i t}}
$$

and meets the conditions of:

$$
\begin{gathered}
w_{j t}>0(j=1, \ldots, n), v_{i t}>0(i=1, \ldots, m) \\
\sum_{i}^{m} v_{i t} x_{i t}=1 \\
E f_{k}=\frac{\sum_{j}^{n} w_{j t} y_{j k}}{\sum_{i}^{m} v_{i t} x_{i k}} \leq 1(k=1, \ldots, r)
\end{gathered}
$$

In this research, the CCR model described above was used [52,53], with constant returns to scale with two inputs and one effect. Consumption of biogas and biomass consumption were assumed as inputs, while the total production of heat from biogas and biomass was assumed as the effect. Data analysis showed that -in this case-constant returns to scale are more appropriate than the alternative-i.e., variable returns to scale. The calculations were performed using the "deaR" package [54] in the R-Studio program. A sensitivity analysis of DEA results was performed using the all-factors-at-once approach. The influence of changes of all variables simultaneously on the relative efficiency was investigated by performing 10,000 simulations. For each variable, a new value was drawn within $\pm 1 \%$ of the original value based on a uniform distribution. The simulation results were presented as an interval for the relative efficiency. This interval was defined by quantiles of the order of 0.025 and 0.975 of simulation results. Thus, $95 \%$ of simulation results were covered by the interval. In order to estimate the potential of biogas production, publicly available statistical data of Statistics Poland were used and the methodology applied in the study by Bujakowski et al. [55] additionally took into account losses and damages in agricultural crops. Biogas is produced in the process of anaerobic digestion of organic waste.

\subsection{Biomass Potential}

In order to estimate the potential of solid biomass, it was assumed that it would come from plant production, including straw surplus, hay surplus, energy crops, orchards, forest production as well as annual felling and care cuts. When calculating the potential offered by the timber management, assumptions from the methodology presented in the work of Bujakowski et al. [55] were included. In order to assess the surplus of straw and hay that can be used for energy purposes, the methodology presented in the study by Ludwicka et al. [56] was used. By calculating the share of the above for special purpose energy crops, it was assumed that the land use factor for growing these plants is $1 / 10$, which is a safe border eliminating competition between the production of raw materials and production for food purposes [57]. When calculating the potential of solid biomass, the biomass that 
could be obtained from the care and replacement of stands in orchards was also taken into account [58].

\section{Results}

\subsection{Regional Differentiation of Biomass and Biogas Potential in Poland}

In Poland, and in particular in voivodeships with a large share of the agricultural economy, an upward trend in electricity consumption has been observed for several years. Electricity consumption is growing faster in rural areas. The share of energy from renewable sources is also increasing, although the growth dynamics is not as high as the EU average [19]. Energy obtained from renewable sources in Poland in 2018 came mainly from solid biofuels (69.3\%), wind energy (12.4\%), and liquid biofuels (10.2\%) [59].

The structure of production of energy from renewable sources for Poland results primarily from the geographic conditions characteristic of our country and possible resources to be managed [60]. The share of energy from renewable sources in the production of primary energy in total increased in 2014-2018 from 12.1\% to $14.3 \%$ [59]. However, it was significantly differentiated regionally (Table 1), which is justified due to the different potential of the resources used for its production. This applies, for example, to organic waste in landfills, animal and vegetable waste on farms, or to the structures and sizes of farms, as indicated by Was et al. [29]. This applies both to the production of biomass and biogas, which are analyzed in this paper.

Table 1. Regional differentiation of potential of biogas and biomass production and use in 2012 and 2018.

\begin{tabular}{|c|c|c|c|c|c|c|c|c|}
\hline \multirow[b]{3}{*}{ Voivodeships } & \multicolumn{4}{|c|}{ Production Potential and Its Use in 2012} & \multicolumn{4}{|c|}{ Production Potential and Its Use in 2018} \\
\hline & \multicolumn{2}{|c|}{ Biogas } & \multicolumn{2}{|c|}{ Biomass } & \multicolumn{2}{|c|}{ Biogas } & \multicolumn{2}{|c|}{ Biomass } \\
\hline & $\begin{array}{l}\text { Production } \\
\text { Potential } \\
\left(\mathrm{dam}^{3}\right)\end{array}$ & $\begin{array}{c}\text { Use of } \\
\text { Potential (\%) }\end{array}$ & $\begin{array}{l}\text { Production } \\
\text { Potential } \\
\text { (tons) }\end{array}$ & $\begin{array}{c}\text { Use of } \\
\text { Potential (\%) }\end{array}$ & $\begin{array}{c}\text { Production } \\
\text { Potential } \\
\left(\mathrm{dam}^{3}\right)\end{array}$ & $\begin{array}{c}\text { Use of } \\
\text { Potential (\%) }\end{array}$ & $\begin{array}{l}\text { Production } \\
\text { Potential } \\
\text { (tons) }\end{array}$ & $\begin{array}{c}\text { Use of } \\
\text { Potential }(\%)\end{array}$ \\
\hline Dolnośląskie & $321,324.6$ & 2.9 & $4,563,028.1$ & 16.8 & $314,818.7$ & 7.7 & $3,953,491.8$ & 5.5 \\
\hline $\begin{array}{l}\text { Kujawsko- } \\
\text { pomorskie }\end{array}$ & $469,096.0$ & 3.7 & $2,892,793.3$ & 51.5 & $481,521.1$ & 5.2 & $3,101,466.5$ & 72.8 \\
\hline Lubelskie & $367,761.7$ & 2.5 & $3,747,584.7$ & 1.6 & $335,812.8$ & 7.2 & $3,873,572.5$ & 1.5 \\
\hline Lubuskie & $141,629.0$ & 12.4 & $4,358,377.3$ & 5.6 & $140,665.7$ & 3.6 & $3,969,589.0$ & 9.1 \\
\hline Łódzkie & $486,559.7$ & 1.6 & $2,601,736.8$ & 14.8 & $476,215.4$ & 2.7 & $2,451,250.0$ & 9.3 \\
\hline Małopolskie & $341,333.1$ & 2.8 & $2,955,906.9$ & 15.1 & $355,141.3$ & 4.7 & 2,589,329.1 & 5.9 \\
\hline Mazowieckie & $987,486.1$ & 2.0 & $5,764,615.9$ & 13.2 & $1,094,449.0$ & 8.3 & $3,890,607.5$ & 31.2 \\
\hline Opolskie & $185,369.8$ & 1.9 & $2,309,445.6$ & 6.3 & $172,393.0$ & 3.2 & $2,142,324.1$ & 3.3 \\
\hline Podkarpackie & $173,942.8$ & 4.5 & $4,119,273.1$ & 4.2 & $167,445.7$ & 8.9 & $3,273,198.6$ & 7.2 \\
\hline Podlaskie & $595,891.8$ & 1.0 & $4,924,012.2$ & 11.1 & $632,614.3$ & 2.1 & $3,174,245.3$ & 7.5 \\
\hline Pomorskie & $304,462.6$ & 14.6 & $4,386,315.3$ & 35.9 & $305,960.8$ & 23.6 & $3,932,233.7$ & 37.4 \\
\hline Śląskie & $379,862.3$ & 6.4 & $2,526,229.1$ & 25.5 & $338,600.2$ & 9.0 & $2,202,212.8$ & 22.5 \\
\hline Świętokrzyskie & $168,925.5$ & 2.2 & $1,906,426.8$ & 42.2 & $159,623.7$ & 3.4 & $1,914,166.3$ & 12.5 \\
\hline $\begin{array}{l}\text { Warmińsko- } \\
\text { mazurskie }\end{array}$ & $364,333.5$ & 1.9 & $7,056,542.1$ & 3.7 & $379,785.0$ & 5.6 & $4,621,153.2$ & 6.9 \\
\hline Wielkopolskie & $945,417.0$ & 1.7 & $5,798,389.8$ & 13.1 & $1,022,612.0$ & 4.1 & $4,771,492.2$ & 8.2 \\
\hline Zachodniopomorskie & $233,444.0$ & 4.3 & $6,011,437.7$ & 17.6 & $235,268.1$ & 7.1 & $5,201,121.4$ & 10.5 \\
\hline Poland & $6,466,839.5$ & 3.3 & $65,922,114.7$ & 15.3 & $6,612,926.7$ & 6.4 & $55,061,454.0$ & 15.4 \\
\hline
\end{tabular}

Source: own study based on the data of the Local Data Bank of Statistics Poland and the Statistics Poland survey of heat from renewable sources (G-02o).

The data in Table 1 show that Pomorskie Voivodeship is the leader in terms of using the potential of biogas production. In 2012, it achieved its potential in terms of biogas production, $14.6 \%$, while in 2018 the use of the potential for biogas production increased to $23.6 \%$. The opposite of Pomorskie Voivodeship is Podlaskie Voivodeship, which was the last in the country in terms of using the potential of biogas production, both in 2012 and 2018. 
Comparing the degree of use of the potential of biogas with the degree of use of the potential of solid biomass, it can be clearly seen that the resources of solid biomass are used far more intensively. In particular, this applies to voivodeships where large power plants and combined heat and power plants operate using the so-called green blocks powered by biomass or cogeneration installations burning solid biomass produced on the site. Such large centers operate in Poland in the following voivodeships: Kujawsko-Pomorskie, Pomorskie, Ślaskie, and Świętokrzyskie, which translates into a high degree of use of the biomass potential in these voivodeships.

\subsection{The Importance of Biogas and Biomass in Meeting Energy Demand in the Regions}

In the further part of the research, the potentials of biogas and biomass were compared, and their total potential in the production of electricity and heat was determined. Then, the data obtained in this way were compared with the statistical data of Statistics Poland on electricity and heat consumption in 2012 and 2018 (Table 2). The equations describing the results of the calculations shown in Table 2 are included in Appendix A.

Table 2. Comparison of the total electricity and heat production potential in 2012 and 2018.

\begin{tabular}{|c|c|c|c|c|c|c|c|c|}
\hline \multirow[b]{2}{*}{ Voivodeships } & \multicolumn{4}{|c|}{2012} & \multicolumn{4}{|c|}{2018} \\
\hline & $\begin{array}{l}\text { Heat Production } \\
\text { Potential/total } \\
\text { Consumption (\%) }\end{array}$ & $\begin{array}{c}\text { Electricity } \\
\text { Production } \\
\text { Potential/Total } \\
\text { Production (\%) }\end{array}$ & $\begin{array}{c}\text { Solid } \\
\text { Biomass/Biogas in } \\
\text { Heat Production }\end{array}$ & $\begin{array}{c}\text { Solid } \\
\text { Biomass/Biogas in } \\
\text { Electricity } \\
\text { Produc-tion }\end{array}$ & $\begin{array}{c}\text { Heat Production } \\
\text { Potential/Total } \\
\text { Consumption (\%) }\end{array}$ & $\begin{array}{c}\text { Electricity } \\
\text { Production } \\
\text { Potential/Total } \\
\text { Production (\%) }\end{array}$ & $\begin{array}{c}\text { Solid } \\
\text { Biomass/Biogas in } \\
\text { Heat Production }\end{array}$ & $\begin{array}{c}\text { Solid } \\
\text { Biomass/Biogas in } \\
\text { Electricity } \\
\text { Production }\end{array}$ \\
\hline Dolnośląskie & 489.7 & 146.2 & 23.0 & 28.4 & 379.5 & 180.7 & 20.2 & 26.1 \\
\hline $\begin{array}{l}\text { Kujawsko- } \\
\text { pomorskie }\end{array}$ & 411.7 & 437.1 & 10.0 & 13.1 & 445.7 & 224.3 & 10.3 & 14.1 \\
\hline Lubelskie & 455.2 & 832.5 & 16.4 & 21.6 & 677.4 & 860.6 & 18.6 & 24.2 \\
\hline Lubuskie & 1633.7 & 791.0 & 49.1 & 66.2 & 1402.2 & 577.6 & 44.7 & 63.4 \\
\hline Łódzkie & 225.2 & 37.1 & 8.9 & 11.7 & 242.9 & 32.4 & 8.5 & 11.5 \\
\hline Małopolskie & 289.4 & 214.4 & 14.1 & 18.1 & 249.3 & 212.4 & 11.8 & 15.8 \\
\hline Mazowieckie & 222.0 & 126.6 & 9.7 & 12.5 & 159.0 & 67.9 & 6.0 & 8.0 \\
\hline Opolskie & 840.7 & 115.9 & 20.2 & 24.1 & 764.3 & 95.0 & 20.0 & 25.5 \\
\hline Podkarpackie & 812.5 & 705.9 & 38.0 & 50.5 & 852.4 & 611.5 & 31.5 & 41.8 \\
\hline Podlaskie & 1018.6 & 3091.2 & 13.6 & 16.9 & 729.5 & 1573.1 & 8.2 & 11.5 \\
\hline Pomorskie & 440.9 & 589.4 & 23.2 & 30.6 & 376.9 & 462.5 & 20.5 & 28.6 \\
\hline Śląskie & 111.0 & 39.0 & 10.7 & 14.3 & 103.9 & 43.7 & 10.5 & 14.3 \\
\hline Świętokrzyskie & 598.5 & 110.8 & 18.4 & 24.8 & 742.0 & 82.9 & 19.4 & 26.8 \\
\hline $\begin{array}{l}\text { Warmińsko- } \\
\text { mazurskie }\end{array}$ & 1298.3 & 4028.6 & 31.6 & 38.3 & 844.9 & 1884.6 & 19.5 & 26.7 \\
\hline Wielkopolskie & 575.4 & 214.0 & 10.0 & 13.1 & 578.8 & 252.5 & 7.6 & 10.6 \\
\hline Zachodniopomorskie & 993.2 & 312.5 & 41.2 & 54.4 & 736.8 & 299.8 & 35.1 & 48.5 \\
\hline Poland & 446.2 & 187.2 & 16.6 & 21.4 & 392.6 & 157.3 & 13.4 & 18.3 \\
\hline
\end{tabular}

Source: own study based on the data of the Local Data Bank of Statistics Poland.

The data presented in Table 2 show that the combined potential of solid biomass and biogas can significantly cover the demand of each voivodeship in terms of thermal energy. In the case of Warmińsko-Mazurskie Voivodeship, heat production may exceed the region's demand more than 12 times, and in the case of electricity, this amount is more than 40 times higher (to illustrate the results in Table 2 better, heat and electricity consumption are included in Appendix B-Table A1). Even in the case of Ślaskie Voivodeship, the weakest in the ranking, biomass may become an important component of the energy mix that is able to fully cover the demand for heat energy and cover $39.2 \%$ of the demand for electricity.

The results also clearly show that the production of both electricity and heat was dominated by solid biomass. Its high share occurred especially in voivodeships characterized by a large share of forest area and a low potential for biogas production-e.g., Lubuskie Voivodeship. 


\subsection{Spatial Diversification of Biogas and Biomass Efficiency}

Individual regions differed in the size and structure of energy sources, as well as the level of efficiency. The data on biogas and biomass consumption and heat production from the unpublished Statistics Poland report on heat from renewable sources being used to compare the effectiveness of useful heat production by voivodeship. The ratio of total heat production from biogas to total biogas consumption was calculated and an analogous index was created for biomass for each of the voivodeships (Table 3).

Table 3. Biogas and biomass efficiency by voivodeship in Poland.

\begin{tabular}{|c|c|c|c|c|c|c|c|c|}
\hline \multirow[b]{3}{*}{ Voivodeships } & \multicolumn{4}{|c|}{2012} & \multicolumn{4}{|c|}{2018} \\
\hline & \multicolumn{2}{|c|}{ Biogas } & \multicolumn{2}{|c|}{ Biomass } & \multicolumn{2}{|c|}{ Biogas } & \multicolumn{2}{|c|}{ Biomass } \\
\hline & $\begin{array}{l}\text { Average } \\
\text { Boiler } \\
\text { Efficiency } \\
\left(\mathrm{MJ} / \mathrm{m}^{3}\right)\end{array}$ & $\begin{array}{c}\text { Weighted } \\
\text { Average Heat } \\
\text { Density } \\
\left(\mathrm{MJ} / \mathrm{m}^{3}\right)\end{array}$ & $\begin{array}{l}\text { Average } \\
\text { Boiler } \\
\text { Efficiency } \\
\text { (MJ/kg) }\end{array}$ & $\begin{array}{c}\text { Weighted } \\
\text { Average } \\
\text { Calorific } \\
\text { Value (MJ/kg) }\end{array}$ & $\begin{array}{l}\text { Average } \\
\text { Boiler } \\
\text { Efficiency } \\
\left(\mathbf{M J} / \mathbf{m}^{3}\right)\end{array}$ & $\begin{array}{l}\text { Weighted } \\
\text { Average Heat } \\
\text { Density } \\
\left(\mathrm{MJ} / \mathrm{m}^{3}\right)\end{array}$ & $\begin{array}{l}\text { Average } \\
\text { Boiler } \\
\text { Efficiency } \\
\text { (MJ/kg) }\end{array}$ & $\begin{array}{c}\text { Weighted } \\
\text { Average } \\
\text { Calorific } \\
\text { Value }(\mathrm{MJ} / \mathrm{kg})\end{array}$ \\
\hline Dolnośląskie & 14.41 & 22.77 & 1.85 & 11.44 & 9.15 & 21.42 & 4.72 & 9.86 \\
\hline $\begin{array}{l}\text { Kujawsko- } \\
\text { pomorskie }\end{array}$ & 6.39 & 21.60 & 5.60 & 11.26 & 6.44 & 22.33 & 8.35 & 8.72 \\
\hline Lubelskie & 11.19 & 21.72 & 7.59 & 15.20 & 6.91 & 20.83 & 8.42 & 15.19 \\
\hline Lubuskie & 4.21 & 19.97 & 5.16 & 9.83 & 8.51 & 21.51 & 5.31 & 11.77 \\
\hline Łódzkie & 10.09 & 23.10 & 1.13 & 11.21 & 10.48 & 21.82 & 1.57 & 10.88 \\
\hline Małopolskie & 9.21 & 21.95 & 2.96 & 15.90 & 8.95 & 22.72 & 6.12 & 10.42 \\
\hline Mazowieckie & 11.90 & 20.85 & 5.30 & 10.34 & 12.19 & 20.55 & 4.12 & 9.02 \\
\hline Opolskie & 10.02 & 21.22 & 1.04 & 12.72 & 5.59 & 20.23 & 3.38 & 16.01 \\
\hline Podkarpackie & 11.54 & 22.02 & 4.11 & 12.80 & 8.81 & 21.80 & 4.64 & 13.00 \\
\hline Podlaskie & 12.87 & 22.41 & 3.11 & 9.48 & 6.88 & 21.47 & 7.01 & 11.58 \\
\hline Pomorskie & 5.62 & 18.56 & 3.28 & 9.02 & 5.58 & 19.14 & 4.02 & 8.86 \\
\hline Śląskie & 9.90 & 21.31 & 1.78 & 15.60 & 9.42 & 22.31 & 2.20 & 11.91 \\
\hline Świętokrzyskie & 8.63 & 19.90 & 0.76 & 12.77 & 9.56 & 20.85 & 2.81 & 13.02 \\
\hline $\begin{array}{l}\text { Warmińsko- } \\
\text { mazurskie }\end{array}$ & 12.97 & 22.02 & 8.50 & 11.58 & 8.84 & 21.17 & 8.86 & 11.84 \\
\hline Wielkopolskie & 4.18 & 21.18 & 3.48 & 11.13 & 6.04 & 21.51 & 9.71 & 12.56 \\
\hline Zachodniopomorskie & 8.47 & 21.88 & 3.39 & 13.01 & 7.25 & 19.78 & 4.97 & 10.60 \\
\hline POLSKA & 8.37 & 20.85 & 3.48 & 11.57 & 8.42 & 20.91 & 5.72 & 10.06 \\
\hline
\end{tabular}

Source: own study based on the data from the Statistics Poland survey of heat from renewable sources (G-02o).

Calorific value is the amount of energy released when $1 \mathrm{~kg}$ of fuel burns; energy density is the amount of energy released when $1 \mathrm{~m}^{3}$ of fuel burns. In the G-02o report, each of the surveyed entities provided calorific values of the fuels, but these values differed even for the same fuel. That is why it was decided to use the concept of average boiler efficiency for biogas and solid biofuel given by instead of calorific value to capture intertemporal technological changes.

$$
\text { Efficiency }=\frac{\text { total heat production in voivodeship }}{\text { total fuel consumption in voivodeship }}\left(\frac{\mathrm{MJ}}{\mathrm{m}^{3}} \text { or } \frac{\mathrm{MJ}}{\mathrm{kg}}\right)
$$

The introduced concept of "efficiency" should not be confused with the concept of energy density and calorific value present in science and technology. In our case, "efficiency" should be treated as an average boiler efficiency for different fuels used in varying proportions and over different periods of time (the installations surveyed were not always in operation throughout the reporting period). In order to illustrate the differences between average boiler efficiency in a given voivodeship and the calorific value of fuel consumed often from different sources, Table 3 also includes the weighted average heat density/calorific value calculated for a given voivodeship. As it is easy to see, the calorific value of biogas is a subject to lower fluctuations than the calorific value of biomass-this 
is due to the fact that biogases from various sources often have similar calorific values, while in the case of biomass, a much greater variability can be observed depending on the type of fuel. Furthermore, only a part of the biomass obtained is used for heat production; in 2012, in Dolnoślaskie Voivodeship, around $24 \%$ of the biomass was used for heat production. In the case of Opolskie Voivodeship, it was slightly over $11 \%$ and in Łódzkie Voivodeship it was $10.7 \%$. In Ślaskie and Świętokrzyskie Voivodeships, it was $16.8 \%$ and $11.3 \%$, respectively. Such low biomass consumption for heat generation translated into low average boiler efficiency.

From 2012 to 2018, biogas consumption increased by $98 \%$ and production by $99 \%$, which, at the country level, translated into a $0.6 \%$ increase in biogas efficiency from 8.37 to $8.42 \mathrm{MJ}$ per kilogram. At the same time, changes in regional terms are very uneven and often inconsistent with the national direction of change. In nine out of sixteen voivodeships, the efficiency of biogas decreased. Undoubtedly, the greatest change took place in Mazowieckie voivodeship, where the production of heat from biogas in 2012-2018 increased $\sim 4.85$ times, and the share of production in Poland increased from $13 \%$ to $31 \%$. At the same time, biogas consumption increased $\sim 4.73$ times, which in total resulted in increase in efficiency from 11.9 to $12.19 \mathrm{MJ}$ per kilogram. This is largely due to changes in the structure of biogas sources. The share of biogas of agricultural origin increased from $29.5 \%$ to $45.7 \%$ at the expense of biogas from sewage treatment plants. As indicated by Kwaśny et al. [61], biogas of agricultural origin has, on average, a higher methane content than biogas from sewage treatment plants.

On a national scale, during the period under examination, the use of biomass fell by $16 \%$, while production increased by $38 \%$, which together increased the efficiency of biomass by as much as $65 \%$. The increase in efficiency occurred in each of the voivodeships. In 2012, only in Warmińsko-Mazurskie Voivodeship was the efficiency of using one kilogram of biomass over $8 \mathrm{MJ}$ per kilogram. For six years, this level was exceeded by Lubelskie, Kujawsko-Pomorskie, and Wielkopolskie Voivodeships, the latter with the highest changei.e., from 3.48 to 9.71. In Wielkopolskie Voivodeship, at the same time, the consumption of resources decreased by nearly $50 \%$ and production increased by $44 \%$.

Naturally, the question arises as to which voivodeships are the most effective in terms of using biocomponents for heat production. Comparing, for example, Podkarpackie and Opolskie Voivodeships, it is easy to say that Podkarpackie is generally more efficient, both in terms of biogas and biomass use. However, it is not easy to compare Dolnoślaskie and Kujawsko-Pomorskie Voivodships. Dolnośląskie Voivodeship makes more efficient use of biogas while Kujawsko-Pomorskie Voivodeship of biomass. Using the partial ranking, the voivodeships can be ranked according to unambiguous comparisons only. The results of the partial ranking are shown in Figures 1 and 2. If there is an arrow from one object to another, it means that the first of them is better than the second one in terms of each analyzed variable. The situation when one can move from the first to the second object through a sequence of arrows with the same direction is interpreted in a similar way. If there is no sequence of arrows between objects, such objects are incomparable. Clusters of voivodeships with similar levels of analysis variables are marked with a gradient color scale, staring from green (the best cluster) and ending on red (the worst cluster).

In 2012, six groups of voivodeships could be distinguished, where a group is shown in the figure as voivodeships at the same height. The best voivodeships are Dolnoślaskie and Warmińsko-Mazurskie Voivodeships, which are leaders in efficiency in biogas and biomass production, respectively. Świętokrzyskie Voivodeship, which is the least efficient in terms of biomass use, is at the other end, together with Pomorskie and Wielkopolskie Voivodeships from the fifth group, with a low biogas efficiency. The 2012-2018 period brought big changes in the partial ranking of voivodeships. The number of groups decreased from six to four. Małopolskie, Dolnoślaskie, and Mazowieckie Voivodeships joined the group of leaders. Among the weakest, compared to 2012, only Pomorskie Voivodeship remained. Together with Opolskie Voivodeship, they were characterized by the lowest efficiency of biogas. Despite the lowest efficiency of biomass in 2018, Łódzkie Voivodeship achieved the 
second best result in terms of biogas efficiency, which resulted in its presence in the second highest group of voivodeships.

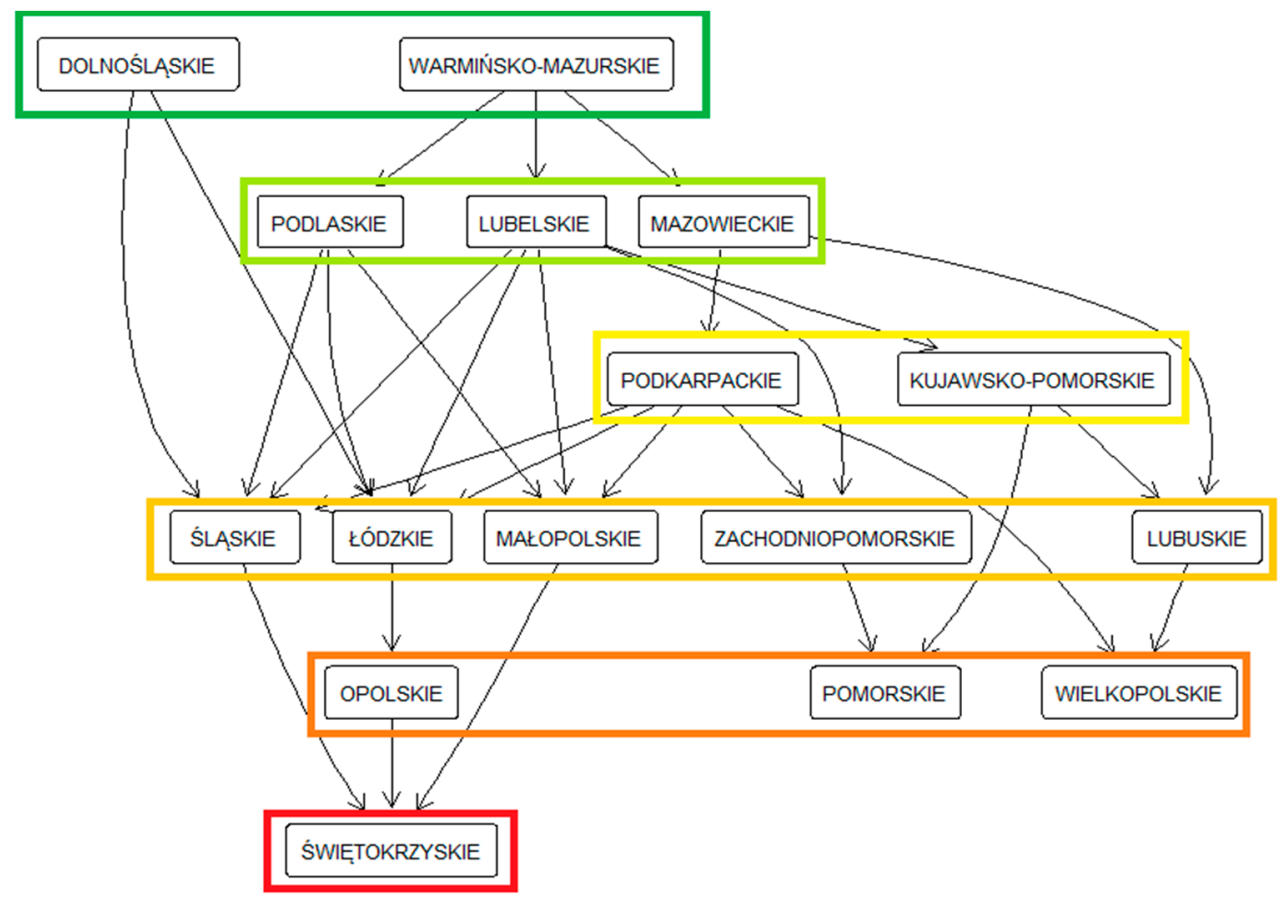

Figure 1. Partial ranking of voivodeships in terms of biogas and biomass efficiency for 2012.

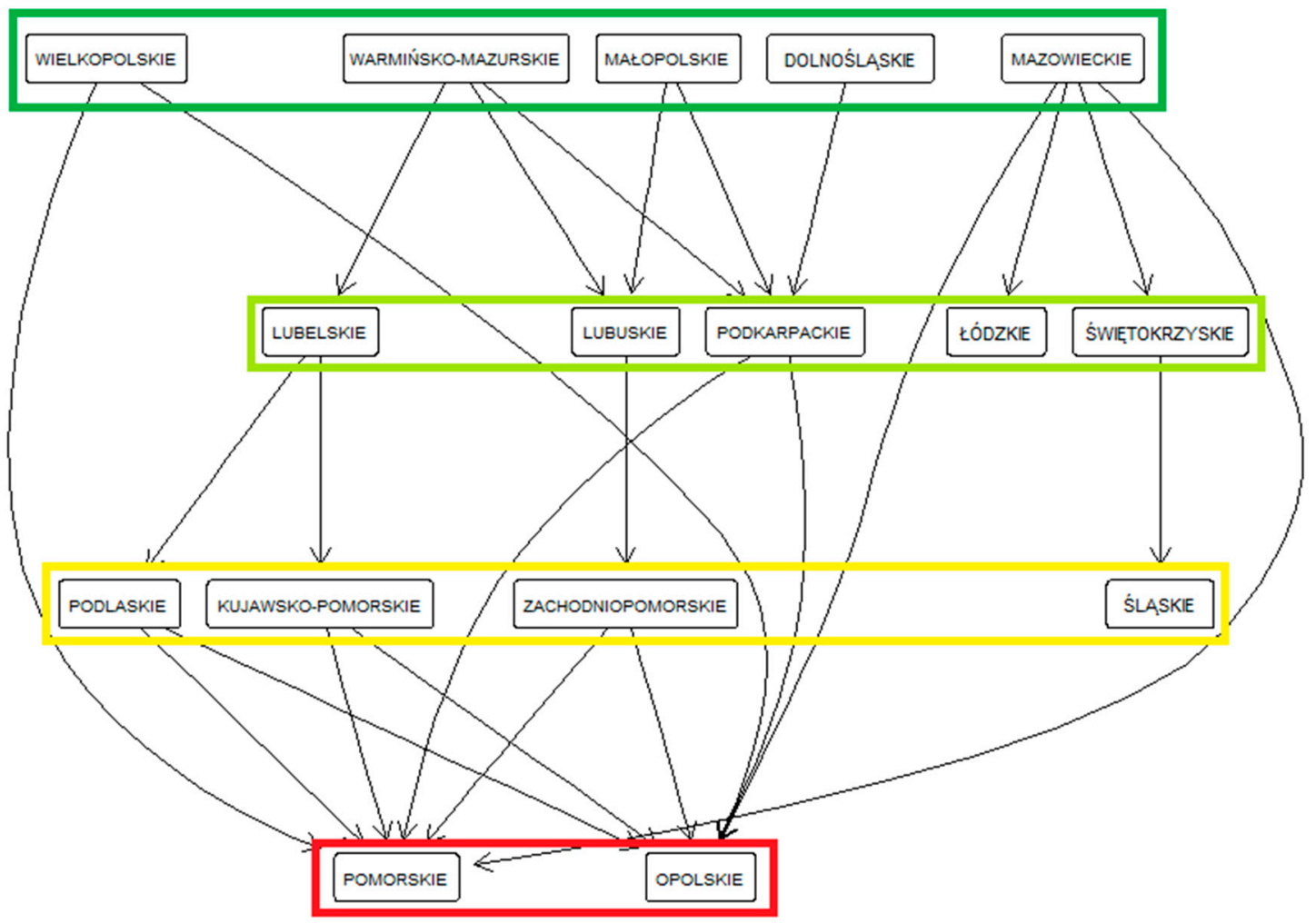

Figure 2. Partial ranking of voivodeships in terms of biogas and biomass efficiency in 2018.

Using the DEA method, the analysis of relative effectiveness of voivodeships in 2012 and 2018 was carried out. The results are presented in Table 4. The DEA analysis 
showed that in 2012 the following voivodeships were effective: Kujawsko-Pomorskie, Lubelskie, and Warmińsko-Mazurskie Voivodeships. Within six years, the group of effective voivodeships was joined by Wielkopolskie Voivodeship, while Warmińsko-Mazurskie voivodeship were minimally distant from the efficiency frontier. In the period 2012-2018, the disparities in terms of effectiveness decreased. The lowest relative efficiency increased from $17.8 \%$ to $23.2 \%$. In 13 out of 16 voivodeships, relative efficiency increased or did not change.

Table 4. Relative efficiency of voivodeships in the production of heat from biogas and biomass including a sensitivity analysis in 2012 and 2018.

\begin{tabular}{ccccc}
\hline \multirow{2}{*}{ Voivodeships } & Relative Efficiency & \multicolumn{2}{c}{$95 \%$ interval } \\
\cline { 2 - 5 } & $\mathbf{2 0 1 2}$ & $\mathbf{2 0 1 8}$ & 2012 & $\mathbf{2 0 1 8}$ \\
\hline Dolnośląskie & 0.350 & 0.554 & $(0.275 ; 0.677)$ & $(0.074 ; 0.709)$ \\
\hline Kujawsko-Pomorskie & 1.000 & 1.000 & $(0.526 ; 1.000)$ & $(0.832 ; 1.000)$ \\
\hline Lubelskie & 1.000 & 1.000 & $(1.000 ; 1.000)$ & $(0.189 ; 1.000)$ \\
\hline Lubuskie & 0.606 & 0.64 & $(0.212 ; 0.963)$ & $(0.578 ; 1.000)$ \\
\hline Łódzkie & 0.178 & 0.232 & $(0.116 ; 0.377)$ & $(0.128 ; 0.308)$ \\
\hline Małopolskie & 0.407 & 0.685 & $(0.311 ; 0.655)$ & $(0.233 ; 0.691)$ \\
\hline Mazowieckie & 0.648 & 0.628 & $(0.788 ; 1.000)$ & $(0.055 ; 0.643)$ \\
\hline Opolskie & 0.152 & 0.391 & $(0.128 ; 0.608)$ & $(0.263 ; 0.501)$ \\
\hline Podkarpackie & 0.519 & 0.548 & $(0.259 ; 0.663)$ & $(0.207 ; 0.807)$ \\
\hline Podlaskie & 0.610 & 0.793 & $(0.359 ; 0.681)$ & $(0.075 ; 0.921)$ \\
\hline Pomorskie & 0.389 & 0.468 & $(0.237 ; 0.854)$ & $(0.441 ; 1.000)$ \\
\hline Śląskie & 0.243 & 0.295 & $(0.138 ; 0.345)$ & $(0.259 ; 0.469)$ \\
\hline Świętokrzyskie & 0.350 & 0.350 & $(0.206 ; 0.570)$ & $(0.315 ; 0.969)$ \\
\hline Warmińsko-Mazurskie & 1.000 & 0.991 & $(0.373 ; 1.000)$ & $(0.214 ; 1.000)$ \\
\hline Wielkopolskie & 0.453 & 1.000 & $(0.402 ; 0.998)$ & $(1.000 ; 1.000)$ \\
\hline Zachodniopomorskie & 0.746 & 0.589 & $(0.620 ; 1.000)$ & $(0.212 ; 0.912)$ \\
\hline & & & &
\end{tabular}

The simulation of the impact of variable changed in the range of $\pm 1 \%$ in the DEA results, showing that the relative efficiency of particularly large voivodeships is sensitive to variable changes. For small voivodeships, e.g., Opolskie, the distribution of results is symmetrical, and the range of results is based on quantiles of the order of 0.025 and 0.975 is narrow. For highly efficient voivodeships, the distribution of results was strongly asymmetric and the range was wide (95\%) (Figure 3).

The completeness of the G-02o report for 2012 in the case of biogas plants amounted to $99 \%$, while in the case of installations burning solid biomass it was over $98 \%$. In 2018 , in the case of biogas plants, the completeness amounted to $92.8 \%$, and in the case of installations burning solid biomass, it was $89 \%$.

In DEA, effective units set the efficiency frontier. Inefficient units lie in the Production Possibility Set. For each of the years, both the efficiency frontier and the Production Possibility Set will be different, so a decrease in the relative efficiency of a voivodeship in subsequent years does not mean that the situation in the voivodeship deteriorated.

The efficiency frontier set by DEA for the CCR model, where the total number of variables (inputs and outputs) does not exceed three in total, can be easily visualized. To this end, indicators were calculated:

$$
\text { Ratio1 }=\frac{\text { heat production from biogas }+ \text { heat production from biomass }}{\text { consumption of biogas }}\left(\frac{\mathrm{MJ}}{\mathrm{m}^{3}}\right)
$$




$$
\text { Ratio2 }=\frac{\text { heat production from biogas }+ \text { heat production from biomass }}{\text { consumption of biomass }}\left(\frac{\mathrm{MJ}}{\mathrm{kg}}\right)
$$
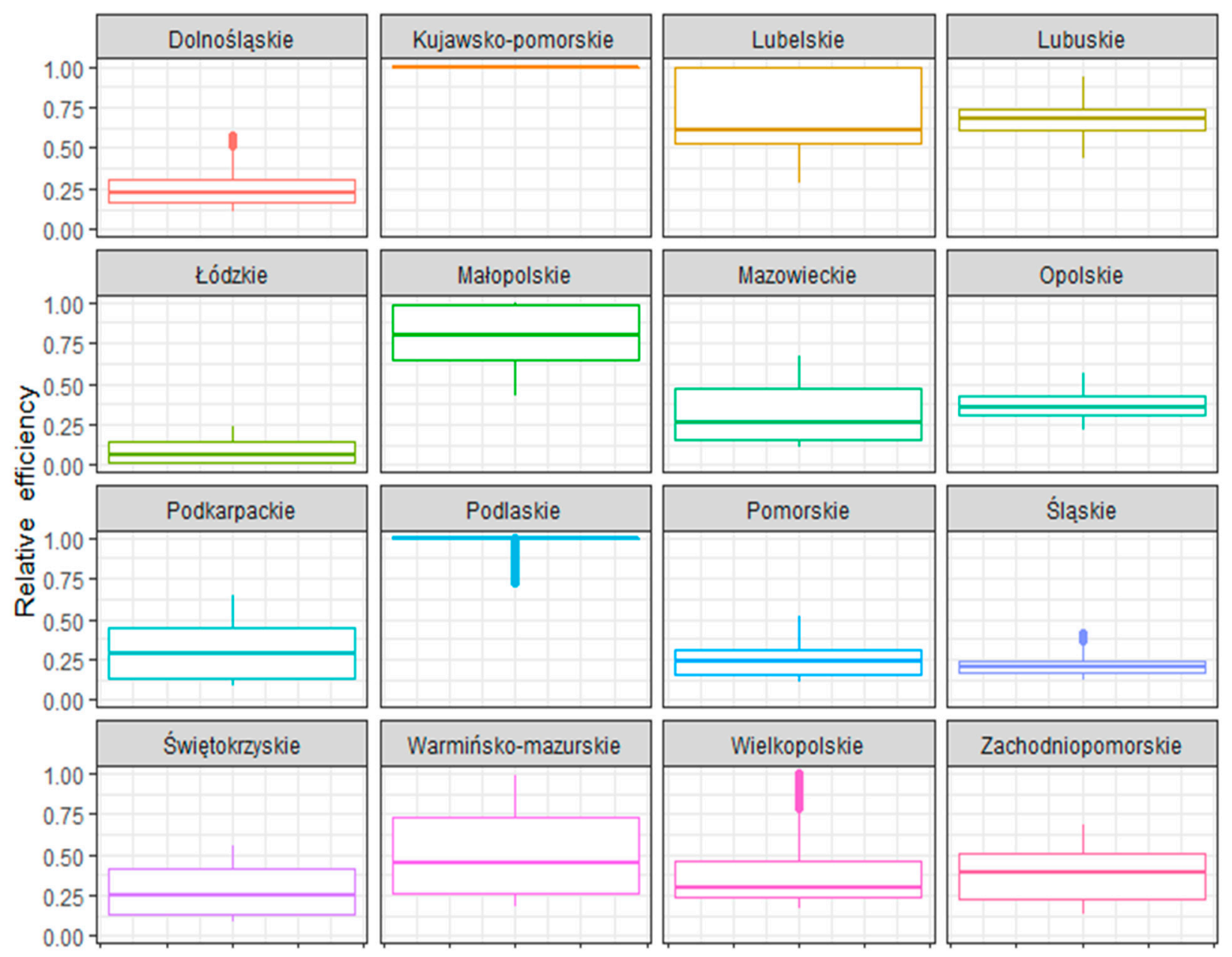

Figure 3. Boxplots of relative efficiency obtained through simulation for voivodeships in 2018.

The numerators of both indicators include heat production from both biogas and biomass, while the denominator refers to the consumption of only one of these components. Thus, these ratios cannot be interpreted in terms of efficiency of heat production from biogas nor biomass, respectively. They are used because they enable the visualization of the efficiency frontier. The results are shown in Figures 4 and 5, covering the years 2012 and 2018, maintaining the same range of scale on both axes. In this way, absolute changes in the years compared can be seen. The pink polygon is the Production Possibility Set and is designated as the convex hull of the effective units, their projections on the axes, and the starting point of the coordinate system. The Production Possibility Set was determined separately for each of the years according to the effective units of that year.

Comparing the effective units in 2012 and 2018, it can be seen that their efficiency frontier moved upwards by $56 \%$ due to biogas and $21 \%$ due to biomass. In the analyzed period, the change of the efficiency limit due to biomass was actually caused by KujawskoPomorskie Voivodeship, whose share in newly produced heat was 78\%. Despite a large relative increase in the production of heat from biogas by $99 \%$ compared to the production of heat from biomass by $38 \%$, the efficiency frontier for biogas did not change much. This is due to the fact that the share of biogas heat production in biomass and biogas heat production was 5\% in 2012 and 7.3\% in 2018. 


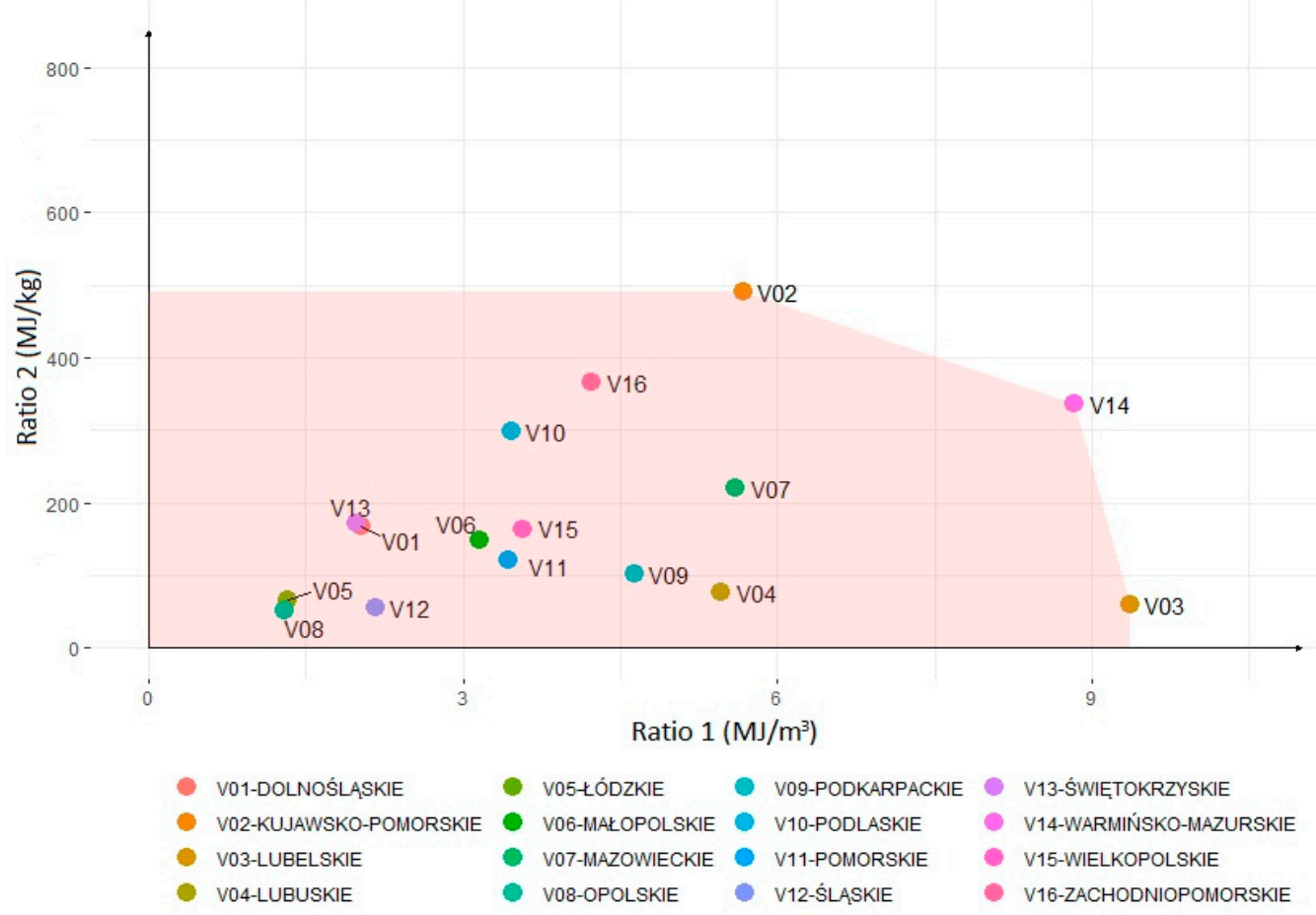

Figure 4. Efficiency of heat production from biogas and biomass in 2012 in Poland.

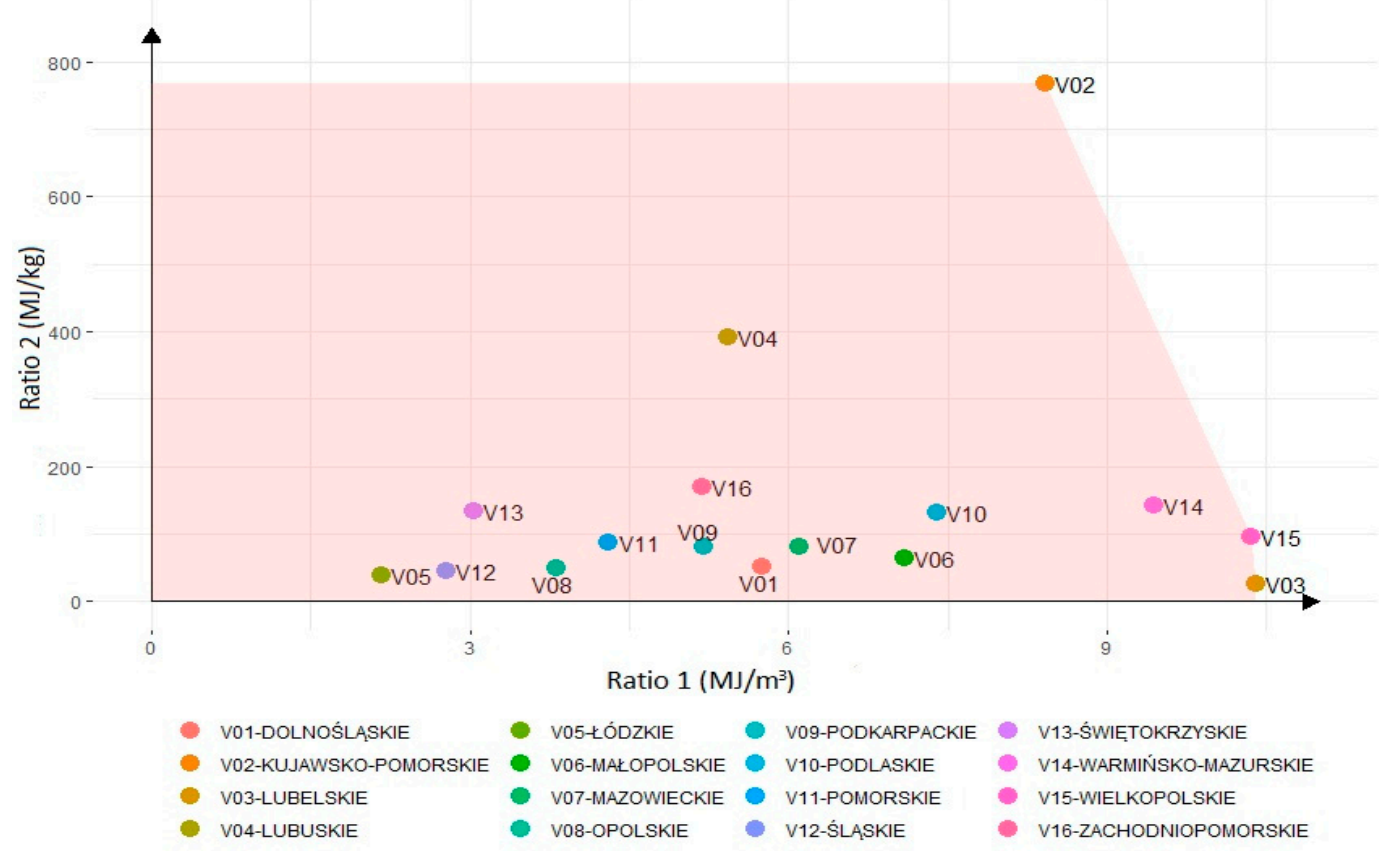

Figure 5. Efficiency of heat production from biogas and biomass in 2018 in Poland.

\section{Discussion}

The importance of assessing the potential of renewable energy sources and assessing energy efficiency in sustainable development is now growing worldwide [62]. Poschl [63] points to ways to increase the efficiency of biogas production by establishing that energy efficiency could be enhanced depending on the use of raw material resources and the adopted technological process. Similar conclusions are presented by Alluvione et al. [64], who note that energy efficiency of agriculture needs improvement to reduce the dependency 
on nonrenewable energy sources. Jalali Sepehr et al. [65] indicate that great opportunities in this respect also arise for developing countries with low incomes, which can achieve high energy efficiency results.

Kaygusuz [66] states that, due to high environmental pollution, renewable energy sources appear to be one of the most efficient and effective solutions for developing clean and sustainable energy. This is particularly important due to inappropriate disposal of agricultural residues (e.g., burning of straw), leading to waste of energy potential and atmospheric environmental problems, as shown in a Chinese study [67]. The use of renewable energy sources is also highlighted by Borhanazad et al. [68], in the context of reducing energy poverty in rural areas of Malaysia. The authors point out not only environmental issues, but, as Kumar did [69], also social and economic ones. Similarly, Pakistan has great potential for renewable energy sources, as Raza et al. [70] stress, adding, however, that in rural areas of Pakistan, this potential is not adequately exploited. Sutherland et al. [71] draw attention to rural areas and agriculture's renewable energy potential, pointing out that the agriculture sector plays an important role in renewable energy transitions, owing to its historical involvement in managing key resources, particularly land and biomass.

However, the rapid increase in the use of biomass for energy purposes is causing concern among many experts around the world, especially with regard to potential threats to sustainable development and food security [72]. This is due to the fact that the production of biomass for energy purposes in agriculture may compete with food production due to a reduction in the area under cultivation for food and feed for livestock [73,74]. Then, as Jasiulewicz [75] points out, the production of biomass for solid fuels should mainly use inferior quality soils, including set-aside and fallow soils, as well as soils contaminated with heavy metals, degraded, particularly unsuitable for the production of consumer crops. The problem of such competition is not observed in the case of biogas, since it is mainly produced from agricultural by-products [76], and the most commonly used substrates for biogas production are manure from cattle, pigs, and poultry litter [62]. This means organic waste that is unfit for consumption or not used for other purposes [77]. It seems, therefore, that biogas is a more acceptable option for energy production.

The results of our calculations, based only on what remains of agricultural production, indicated a significant decrease in the technical resources of biomass, which took place between 2012 and 2018. According to our calculations in 2012, the potential for obtaining thermal energy from biomass reached the level of $907 \mathrm{PJ}$ (which fits well the value given by Bartoszewicz-Burczy [78]), of which 856 PJ came from solid biomass (65.9 million tons) and only $51 \mathrm{PJ}$ from biogas $\left(6.46\right.$ billion $\left.\mathrm{m}^{3}\right)$. In 2018, the biomass potential decreased to the level of 752 PJ, where 700 PJ came from solid biomass (55.1 million tons) and 52 PJ from biogas $\left(6.61\right.$ billion $\mathrm{m}^{3}$ ). The decrease in the potential of solid biomass was caused by a decrease in the amount of wood that could be harvested from pruning (a decrease of about 1.9 million tons) and a decrease in surplus straw (about 2.8 million tons) and hay (about 8.8 million tons) that could be harvested. As can be seen, solid biomass, having a much greater share, is a more unstable energy source than biogas, which, after purification to the biomethane standard, could cover $20 \%-25 \%$ of the demand for natural gas in Poland (according to consumption for 2018). This creates wide opportunities for the development of this energy sector in the areas so far associated in Poland mainly with agricultural activities (e.g., Podlaskie Voivodeship).

In this context, it is also worth paying attention to other European countries that use biomass resources. As can be seen from the example of selected European countries (Table 5), the estimated biomass potential shows a large diversity, which results not only from the methodology of calculation, but also depends on the changes taking place in the biomass sources themselves (development of sewage infrastructure, change in the nature of crops, drought or legal restrictions). The biomass potential in Poland is comparable to countries with a similar area, such as Italy or Germany; however, per capita, it is one of the best among the compared countries in Central Europe (Table 5). Taking into account the consumption of natural gas in 2018 , the maximum use of the potential of biogas production 
in Germany would cover about $10 \%$ of the country's demand for natural gas; in the case of Czech Republic, it would be around $12 \%$; for Hungary this value is around $9 \%$, while for Italy it is less than $7 \%$ [43].

Table 5. Biomass potential for Central European countries per capita (where: $1 \mathrm{PJ}=10^{9} \mathrm{MJ}, 1 \mathrm{GJ}=10^{3} \mathrm{MJ}$ ).

\begin{tabular}{ccc}
\hline Country & Total Biomass Potential (PJ) & Biomass Potential per Person (GJ/person) \\
\hline Czech Republic & 300 & 28.16 \\
\hline Germany & $560-1050$ & $6.74-12.64$ \\
\hline Hungary & $153-190$ & $15.60-19.37$ \\
\hline Italy & $1094-1260$ & $18.08-20.83$ \\
\hline Poland & 900 & 23.44 \\
\hline Slovenia & $28-53$ & $13.57-25.70$ \\
\hline Slovakia & $90 \quad$ Source: $[78]$.
\end{tabular}

The importance of renewable energy in the Polish economy is growing, although Poland still has one of the highest carbon dioxide emission figures in Europe in relation to electricity produced [79]. Therefore, the increase in energy efficiency in the regions may contribute to the increase in the national energy supply potential. The use of renewable resources as substitute energy sources is a factor improving the security of energy supply [80]. The increase in energy efficiency of renewable energy sources contributes to the reduction in greenhouse gas emissions [81]. It is, therefore, necessary to increase the efficiency and consumption of renewable energy [82].

The raw material resources and natural conditions, as well as modern technologies, are not always sufficient for the transition to renewable resources. It may turn out that the exploitation of a given energy resource will not be profitable without state support. Currently, such production in many countries is more expensive than energy produced from fossil resources [83]. Similar conclusions were reached by Radziszewska-Zielina and Rumin [84], indicating that unconventional energy sources in Poland are relatively expensive. However, the results of our analyses indicate a very high potential of both biomass and biogas, which could be used more widely, contributing to the reduction in fossil fuel use. A proper state energy policy, which is also indicated by Jedlińska [85] and action at a local level are therefore needed, especially in the era of energy transformation and withdrawal from coal in the energy sector.

\section{Conclusions}

The research carried out indicates that Poland has significant biomass and biogas potential. However, it is regionally differentiated. At a national scale, Pomorskie Voivodeship is the leader in terms of using the biogas production potential. The opposite is Podlaskie Voivodeship, which both in 2012 and 2018 was lowest ranked in the country. Comparing the years 2012 and 2018, it should be pointed out that, in Poland, the use of the potential for the production of heat from biogas and also from biomass almost tripled, although in the latter case to a lesser extent. Our analyses show that, in the same period, there was an increase in the efficiency of the use of both biogas and biomass, with a higher increase in efficiency for biomass. This is due to structural changes in energy carriers and an increase in the technical efficiency of heat production. The DEA analysis showed that the highest relative technical efficiency in 2012 was achieved by three voivodeships: Kujawsko-Pomorskie, Warmińsko-Mazurskie, and Lubelskie. In 2018, Wielkopolskie Voivodeship joined them. This was associated with the developing agri-food industry producing waste biomass yields, as well as an increase in the market for processed biomass (including an increase in the number of biogas plants from 183 in 2012 to 293 in 2018). 
In the case of Podlaskie Voivodeship, which is distinguished in the country by the highest cattle population per 100 ha of farmland, the use of the biogas production potential reached only $2.1 \%$ in 2018 . However, "activating" the potential to produce heat from biogas would ensure self-sufficiency in this region. The remaining regions, on the other hand, could achieve energy self-sufficiency if the use of solid biomass was increased. At the national scale, however, the potential of biogas may be more important than in the countries of Central Europe, as in the case of Poland, it may cover more than $20 \%$ of the demand for natural gas, which, in the case of the upcoming energy transformation (moving away from coal), may prove to be a very important contribution of Polish agriculture. This is confirmed by the results of our research, which indicates that biogas, as opposed to solid biomass, is a more stable energy source (52 PJ in 2018).

It should also be noted that the presented results are based on available statistical data. An obstacle to more accurate estimates was the lack of detailed, available data on elements of the potential of both biomass and biogas. These data, derived from farms and rural areas, may be incomplete, which may affect the accuracy of the calculations. In the case of estimating the potential of biogas production, due to the lack of data, the crop production grown for the input of biogas plants was not taken into account and nor was the share of postproduction waste supplied by the food industry. Moreover, the lower boundaries of the biogas production efficiency from a given raw material were taken into account. In the case of estimating the production potential of solid biomass, due to the lack of data, the share of postproduction waste supplied by the paper and cellulose industry was not taken into account.

However, it should be pointed out that the studies carried out by our team are one of a few in Poland, as well as in Central and Eastern European countries. However, taking into account the available literature, the presented work significantly fills the knowledge gap on the discussed problem.

Author Contributions: Conceptualization, G.Ś. and B.G.; methodology, M.C.-W., D.T. and S.W.; software, S.W. and D.T.; validation, S.W. and D.T.; formal analysis, B.G., D.T., S.W. and G.S.; investigation, J.G., M.C.-W., D.T. and S.W.; resources, S.W., M.C.-W. and D.T.; data curation, S.W. and D.T.; writing-original draft preparation, G.Ś., B.G., D.T., S.W. and M.C-W; writing-review and editing, B.G. and J.G.; visualization, B.G. and S.W.; supervision, G.S.; project administration, G.S., B.G. and J.G.; funding acquisition, G.Ś. and B.G. All authors have read and agreed to the published version of the manuscript.

Funding: This research received no external funding.

Institutional Review Board Statement: Not applicable.

Informed Consent Statement: Not applicable.

Conflicts of Interest: The authors declare no conflict of interest.

\section{Appendix A}

The equations describing the calculation of the ratio of heat production potential to consumption in Table 2:

$$
\frac{\text { heat }}{\text { total }} \text { consumption }=\frac{\text { heat production potential } * 100 \%}{\text { total heat consumption }},
$$

where:

heat production potential $=$ biogas heat $p . p+$ straw heat $p \cdot p+$ hay heat $p \cdot p+$ wood heat $p \cdot p+$ energy crop heat $p \cdot p$

heat p.p-heat production potential.

$$
\text { biogas heat } p . p=\text { biogas production potential }\left[m^{3}\right] * 23\left[\frac{M J}{m^{3}}\right] \text {, }
$$




$$
\begin{gathered}
\text { biogas heat } p . p=\text { biogas production potential }\left[\mathrm{m}^{3}\right] * 23\left[\frac{\mathrm{MJ}}{\mathrm{m}^{3}}\right] \\
\text { straw heat } p . p=\text { excess straw production }[\mathrm{kg}] * 13.1\left[\frac{\mathrm{MJ}}{\mathrm{kg}}\right], \\
\text { hay heat } p . p=\text { excess hay production }[\mathrm{kg}] * 13.4\left[\frac{\mathrm{MJ}}{\mathrm{kg}}\right], \\
\text { wood heat } p \cdot p=\text { wood production potential }[\mathrm{kg}] * 12.4\left[\frac{\mathrm{MJ}}{\mathrm{kg}}\right], \\
\text { energy crop heat } p \cdot p=\text { energy crop production potential }[\mathrm{kg}] * 17\left[\frac{\mathrm{MJ}}{\mathrm{kg}}\right] .
\end{gathered}
$$

The equations describing the calculation of the ratio of electricity production potential to electricity production in the studied years:

$$
\text { electricity/total production }=\frac{\text { electricity production potential } * 100 \%}{\text { total electricity prodution }},
$$

where:

electricity production potential $=$ biogas el.p.p + straw el.p.p + hay el.p.p + wood el.p.p + energy crop el.p.p,

el.p.p-electricity production potential.

$$
\begin{gathered}
\text { biogas el.p.p }=\text { biogas production potential }\left[\mathrm{m}^{3}\right] * 6.3\left[\frac{\mathrm{kWh}}{\mathrm{m}^{3}}\right], \\
\text { straw el.p.p }=\text { excess straw production }[\mathrm{kg}] * 3.46\left[\frac{\mathrm{kWh}}{\mathrm{kg}}\right], \\
\text { hay el.p.p }=\text { excess hay production }[\mathrm{kg}] * 3.46\left[\frac{\mathrm{kWh}}{\mathrm{kg}}\right], \\
\text { wood el.p.p }=\text { wood production potential }[\mathrm{kg}] * 4.8\left[\frac{\mathrm{kWh}}{\mathrm{kg}}\right], \\
\text { energy crop el.p.p }=\text { energy crop production potential }[\mathrm{kg}] * 4.1\left[\frac{\mathrm{kWh}}{\mathrm{kg}}\right],
\end{gathered}
$$

Ratio of heat and electricity production potential from solid biomass to biogas production potential:

$$
\text { solid biomass / biogas in heat production }=\frac{\text { solid biomass heat production potential }}{\text { biogas heat } p . p},
$$

solid biomass/biogas in electricity production $=\frac{\text { solid biomass electricity production potential }}{\text { biogas el. } p . p}$. 


\section{Appendix B}

Table A1. Consumption of heat energy and production of electricity.

\begin{tabular}{ccccc}
\hline Voivodeships & \multicolumn{2}{c}{$\mathbf{2 0 1 2}$} & \multicolumn{2}{c}{$\mathbf{2 0 1 8}$} \\
\cline { 2 - 5 } & $\begin{array}{c}\text { Thermal Energy } \\
\text { Consumption } \\
\text { (GJ) }\end{array}$ & $\begin{array}{c}\text { Electricity } \\
\text { Production } \\
\text { (GWh) }\end{array}$ & $\begin{array}{c}\text { Thermal Energy } \\
\text { Consumption } \\
\text { (GJ) }\end{array}$ & $\begin{array}{c}\text { Electricity } \\
\text { Production } \\
\text { (GWh) }\end{array}$ \\
\hline Dolnośląskie & $12,587,790.0$ & $13,567.7$ & $14,067,201.0$ & 9917.7 \\
\hline $\begin{array}{c}\text { Kujawsko- } \\
\text { pomorskie }\end{array}$ & $9,989,713.3$ & 3177.6 & $9,790,920.0$ & 6798.8 \\
\hline Lubelskie & $11,249,543.0$ & 2100.7 & $7,761,207.0$ & 2066.8 \\
\hline Lubuskie & $3,476,022.3$ & 2524.7 & $3,665,305.0$ & 3290.8 \\
\hline Łódzkie & $17,100,953.0$ & $34,968.5$ & $14,969,554.0$ & $38,641.0$ \\
\hline Małopolskie & $14,244,845.0$ & 6384.5 & $14,587,770.0$ & 5888.7 \\
\hline Mazowieckie & $38,045,642.0$ & $22,090.0$ & $38,352,261.0$ & $30,441.0$ \\
\hline Opolskie & $3,743,473.0$ & 8442.2 & $3,786,207.0$ & $10,087.2$ \\
\hline Podkarpackie & $6,682,073.0$ & 2664.7 & $5,101,140.0$ & 2462.0 \\
\hline Podlaskie & $6,840,182.0$ & 723.4 & $6,362,132.0$ & 1051.2 \\
\hline Pomorskie & $13,353,847.0$ & 3426.3 & $13,953,962.0$ & 4104.9 \\
\hline Sląskie & $32,089,653.0$ & $31,249.5$ & $29,878,280.0$ & $24,905.9$ \\
\hline Świętokrzyskie & $4,371,481.0$ & 8268.3 & $3,514,462.0$ & $11,213.1$ \\
\hline Warmińsko- & $7,312,422.0$ & 745.6 & $7,361,499.0$ & 1170.2 \\
\hline mazurskie & $14,447,636.5$ & $13,112.6$ & $12,129,926.0$ & 9840.7 \\
\hline Wielkopolskie & $7,934,129.0$ & 8692.8 & $9,230,561.0$ & 8159.4 \\
\hline POLhodniopomorskie & $203,469,405.1$ & $162,139.1$ & $194,512,387.0$ & $170,039.5$ \\
\hline
\end{tabular}

Source: Local Data Bank of Statistics Poland.

\section{References}

1. Howells, M.; Hermann, S.; Welsch, M.; Bazilian, M.; Segerström, R.; Alfstad, T.; Ramma, I. Integrated analysis of climate change, land-use, energy and water strategies. Nat. Clim. Change 2013, 3, 621-626. [CrossRef]

2. Ritchie, H.; Roser, M. Fossil Fuels. Our World Data. 2017. Available online: https:/ / ourworldindata.org/fossil-fuels (accessed on 16 December 2020).

3. Arıŏlu Akan, M.; Selam, A.; Oktay Fırat, S.; Er Kara, M.; Özel, S. A Comparative Analysis of Renewable Energy Use and Policies: Global and Turkish Perspectives. Sustainability 2015, 7, 16379-16407. [CrossRef]

4. Moomaw, W.; Yamba, F.; Kamimoto, M.; Maurice, L.; Nyboer, J.; Urama, K.; Weir, T. Introduction. In IPCC Special Report on Renewable Energy Sources and Climate Change Mitigation; Edenhofer, O., Pichs-Madruga, R., Sokona, Y., Seyboth, K., Matschoss, P., Kadner, S., Zwickel, T., Eickemeier, P., Hansen, G., Schlömer, S., et al., Eds.; Cambridge University Press: Cambridge, UK, 2011.

5. Eurostat. Energy Statistics-An Overview. Available online: https://ec.europa.eu/eurostat/statistics-explained (accessed on 17 December 2020).

6. Chel, A.; Kaushik, G. Renewable energy for sustainable agriculture. Agron. Sustain. Dev. 2011, 31, 91-118. [CrossRef]

7. Bishoge, O.K.; Kombe, G.G.; Mvile, B.N. Renewable energy for sustainable development in sub-Saharan African countries: Challenges and way forward. J. Renew. Sustain. Energy 2020, 12, 052702. [CrossRef]

8. Gielen, D.; Boshell, F.; Saygin, D.; Bazilian, M.D.; Wagner, N.; Gorini, R. The role of renewable energy in the global energy transformation. Energy Strateg. Rev. 2019, 24, 38-50. [CrossRef]

9. Kibria, G. Sustainable Energy for Rural Development in Developing Countries- Economic, Social, and Environmental Benefits of Renewable Energy. A Case Study. Sci. Technol. Artic. 2015, 37. [CrossRef]

10. Poggi, F.; Firmino, A.; Amado, M. Planning renewable energy in rural areas: Impacts on occupation and land use. Energy 2018, 155, 630-640. [CrossRef]

11. Gradziuk, P.; Gradziuk, B. Renewable Energy Sources as a Development Opportunity for Peripheral Areas. Econ. Reg. Stud. 2020, 13, 184-198. [CrossRef] 
12. Lemaire, X. Off-Grid electrification with solar home systems: The experience of a fee-for-service concession in South Africa. Energy Sustain. Dev. 2011, 15, 277-283. [CrossRef]

13. Abolhosseini, S.; Heshmati, A.; Altmann, J. A Review of Renewable Energy Supply and Energy Efficiency Technologies. IZA Discuss. Pap. Ser. 2014, 8145, 1-35.

14. European Parliament. Directive 2009/28/EC of the European Parliament and of the Council of 23 April 2009 on the Promotion of the Use of Energy from Renewable Sources and Amending and Subsequently Repealing Directives 2001/77/EC and 2003/30/EC; European Parliament: Brussels, Belgium, 2009.

15. European Parliament. Communication from the Commission to the European Parliament and the Council. Energy Efficiency and Its Contribution to Energy Security and the 2030 Framework for Climate and Energy Policy; European Parliament: Brussels, Belgium, 2014

16. European Commission. Rozporzadzenie Parlamentu Europejskiego i Rady w Sprawie Rocznych Ograniczeń Emisji Gazów Cieplarnianych Przez Państwa Członkowskie w Latach 2021-2030 na Rzecz Stabilnej Unii Energetycznej i w Celu Wywiazania się ze Zobowiazań Wynikajacych z Porozumienia Paryskiego, Oraz Zmieniajace Rozporzadzenie Parlamentu Europejskiego i Rady nr 525/2013 w Sprawie Mechanizmu Monitorowania i Sprawozdawczości w Zakresie Emisji Gazów Cieplarnianych Oraz Zgłaszania Innych Informacji Majacych Znaczenie dla Zmiany Klimatu (Regulation of the European Parliament and of the Council on Binding Annual Greenhouse Gas Emission Reductions by Member States from 2021 to 2030 for a Resilient Energy Union and to Meet Commitments under the Paris Agreement and Amending Regulation (EU) No 525/2013 of the European Parliament and the Council on a Mechanism for Monitoring and Reporting Greenhouse Gas Emissions and Other Information Relevant to Climate Change); European Commission: Brussels, Belgium, 2016.

17. Government Gazzete of the Republic of Poland. Strategia na rzecz Odpowiedzialnego Rozwoju (Strategy for Responsible Development) M.P poz. 260 Uchwała NR 8 Rady Ministrów z dnia 14 lutego 2017 roku w Sprawie Przyjęcia Strategii na rzecz Odpowiedzialnego Rozwoju do Roku 2020 ( $z$ perspektywa do 2030 roku); The Polish Monitor: Warsaw, Poland, 2017.

18. EPA. Greenhouse Gas Emissions. Global Emissions by Economic Sector, Washington: United States Environmental Protection Agency. Available online: https:/ / www.epa.gov/ (accessed on 16 December 2020).

19. GUS. Energy, Central Statistical Officce, Warsaw. Available online: https:/ / stat.gov.pl (accessed on 12 December 2020).

20. Mirowski, T.; Jach-Nocoń, M.; Jelonek, I.; Nocon, A. The new meaning of solid fuels from lignocellulosic biomass used in low-emission automatic pellet boilers. Energy Policy J. 2020, 23, 75-86.

21. Pawlak, J. Produkcja i zużycie energii odnawialnej w Polsce ze szczególnym uwzględnieniem rolnictwa (Production and Consumption af Renewable Energy in Poland with a Special Regard to Agriculture). Probl. Agric. Eng. 2016, 4, 67-76.

22. Sulewski, P.; Majewski, E.; Was, A. Miejsce i rola rolnictwa w produkcji energii odnawialnej w Polsce i UE (The importance of agriculture in the renewable energy production in poland and the EU). Zagadnienia Ekonomiki Rolnej 2017, 1, 50-74. [CrossRef]

23. Woźniak, M. Zrównoważona gospodarka energetyczna na obszarach wiejskich w Polsce (A sustainable energy economy in rural areas in Poland). Policy J. 2018, 21, 69-84.

24. Hengeveld, E.J.; Bekkering, J.; van Gemert, W.J.T.; Broekhuis, A.A. Biogas infrastructures from farm to regional scale, prospects of biogas transport grids. Biomass Bioenergy 2016, 86, 43-52. [CrossRef]

25. Carrosio, G. Energy production from biogas in the Italian countryside: Policies and organizational models. Energy Policy 2013, 63, 3-9. [CrossRef]

26. Yang, Y.; Zhang, P.; Li, G. Regional differentiation of biogas industrial development in China. Renew. Sustain. Energy Rev. 2012, 16, 6686-6693. [CrossRef]

27. Yin, D.; Liu, W.; Zhai, N.; Wang, Y.; Ren, C.; Yang, G. Regional differentiation of rural household biogas development and related driving factors in China. Renew. Sustain. Energy Rev. 2017, 67, 1008-1018. [CrossRef]

28. Roubík, H.; Mazancová, J.; Rydval, J.; Kvasnička, R. Uncovering the dynamic complexity of the development of small-scale biogas technology through causal loops. Renew. Energy 2019, 1-21. [CrossRef]

29. Wąs, A.; Sulewski, P.; Krupin, V.; Popadynets, N.; Malak-Rawlikowska, A.; Szymańska, M.; Wysokiński, M. The Potential of Agricultural Biogas Production in Ukraine-Impact on GHG Emissions and Energy Production. Energies 2020, $13,5755$. [CrossRef]

30. Groscurth, H. Total costs and benefits of biomass in selected regions of the European Union. Energy 2000, 25, 1081-1095. [CrossRef]

31. Sağlam, U. The Efficiency Assessment of Renewable Energy Sources with Data Envelopment Analysis. SSRN Electron. J. 2018, 1-13. [CrossRef]

32. Sornek, K. Prototypical Biomass-Fired Micro-Cogeneration Systems-Energy and Ecological Analysis. Energies 2020, 13, 3909. [CrossRef]

33. Chodkowska-Miszczuk, J.; Szymańska, D. Agricultural biogas plants-A chance for diversification of agriculture in Poland. Renew. Sustain. Energy Rev. 2013, 20, 514-518. [CrossRef]

34. Lombard, A.; Ferreira, S.L.A. The spatial distribution of renewable energy infrastructure in three particular provinces of South Africa. Bulletin of Geography. Soc. Econ. Ser. 2015, 30, 71-85. [CrossRef]

35. Wang, Q.; Kwan, M.-P.; Fan, J.; Zhou, K.; Wang, Y.-F. A study on the spatial distribution of the renewable energy industries in China and their driving factors. Renew. Energy 2019, 139, 161-175. [CrossRef]

36. Stoeglehner, G.; Niemetz, N.; Kettl, K.H. Spatial dimensions of sustainable energy systems: New visions for integrated spatial and energy planning. Energy Sustain. Soc. 2011, 1, 2. [CrossRef]

37. Moreda, I.L. The potential of biogas production in Uruguay. Renew. Sustain. Energy Rev. 2016, 54, 1580-1591. [CrossRef] 
38. Roubík, H.; Mazancova, J. Suitability of small-scale biogas systems based on livestock manure for the rural areas of Sumatra. Environ. Dev. 2020, 33, 100505. [CrossRef]

39. Van Zalk, J.; Behrens, P. The spatial extent of renewable and non-renewable power generation: A review and meta-analysis of power densities and their application in the U.S. Energy Policy 2018, 123, 83-91. [CrossRef]

40. Park, B.; Hur, J. Spatial Prediction of Renewable energy resources for reinforcing and expanding power grids. Energy 2018, 164, 757-772. [CrossRef]

41. Frantál, B.; Nováková, E. En the spatial differentiation of energy transitions: Exploring determinants of uneven wind energy developments in the Czech Republic. Morav. Geogr. Rep. 2019, 27. [CrossRef]

42. Zawada, M. Spatial differentiation of renewable energy sources use in the European Union countries in the years 2001-2013 Materials, Methods \& Technologies. J. Int. Sci. Publ. 2015, 9, 80-94.

43. Scarlat, N.; Fahl, F.; Dallemand, J.-F.; Monforti, F.; Motola, V. A spatial analysis of biogas potential from manure in Europe. Renew. Sustain. Energy Rev. 2018, 94, 915-930. [CrossRef]

44. Mardani, A.; Streimikiene, D.; Balezentis, T.; Saman, M.; Nor, K.M.; Khoshnava, S. Data Envelopment Analysis in Energy and Environmental Economics: An Overview of the State-of-the-Art and Recent Development Trends. Energies 2018, 11, 2002. [CrossRef]

45. Olanrewaju, O.; Jimoh, A.; Kholopane, P. Integrated IDA-ANN-DEA for assessment and optimization of energy consumption in industrial sectors. Energy 2012, 46, 629-635. [CrossRef]

46. Lee, S.K.; Mogi, G.; Hui, K.S. A fuzzy analytic hierarchy process (AHP)/data envelopment analysis (DEA) hybrid model for efficiently allocating energy R\&D resources: In the case of energy technologies against high oil prices. Renew. Sustain. Energy Rev. 2013, 21, 347-355.

47. Han, Y.; Geng, Z.; Gu, X.; Zhu, Q. Energy efficiency analysis based on DEA integrated ISM: A case study for Chinese ethylene industries. Eng. Appl. Artif. Intell. 2015, 45, 80-89. [CrossRef]

48. Xu, T.; You, J.; Li, H.; Shao, L. Energy Efficiency Evaluation Based on Data Envelopment Analysis: A Literature Review. Energies 2020, 13, 3548. [CrossRef]

49. Farrell, M.J. The Measurement of Productive Efficiency. J. R. Stat. Soc. Ser. A 1957, 120, 253-281. [CrossRef]

50. Mardani, A.; Zavadskas, E.K.; Streimikiene, D.; Jusoh, A.; Khoshnoudi, M. A comprehensive review of data envelopment analysis (DEA) approach in energy efficiency. Renew. Sustain. Energy Rev. 2017, 70, 1298-1322. [CrossRef]

51. Shabanpour, H.; Yousefi, S.; Saen, R.F. Forecasting efficiency of green suppliers by dynamic data envelopment analysis and artificial neural networks. J. Clean. Prod. 2017, 142, 1098-1107. [CrossRef]

52. Charnes, A.; Cooper, W.W.; Rhodes, E. Measuring the efficiency of decision making units. Eur. J. Oper. Res. 1978, 2, 429-444. [CrossRef]

53. Charnes, A.; Cooper, W.W.; Golany, B.; Seiford, L.M.; Stutz, J. Foundations of Data Envelopment. Analysis for Pareto-Koopman's Efficient Empirical Production Functions. J. Econom. 1985, 30, 91-107. [CrossRef]

54. Coll-Serrano, V.; Bolos, V.; Benitez Suarez, R. deaR: Conventional and Fuzzy Data Envelopment. Analysis. R Package v1.2.1. Available online: https: / /CRAN.R-project.org/package=deaR (accessed on 12 December 2020).

55. Bujakowski, W.; Barbacki, A.; Grzybek, A.; Hołojuch, G.; Pajak, L.; Skoczek, A.; Skrzypczak, M.; Skrzypczak, S. Opracowanie Metody Programowania i Modelowania Systemów Wykorzystania Odnawialnych źródeł Energii na Terenach Nieprzemysłowych Województwa Slaskiego, wraz z Programem Wykonawczym dla Wybranych Obszarów Województwa-Częśc I: Metodyka Opracowania; Instytut Gospodarki Surowcami Mineralnymi i Energią PAN: Kraków, Poland, 2005; p. 55.

56. Ludwicka, A.; Grzybek, A. Bilans masy rolnej (słomy) na potrzeby energetyki (Balance of the agricultural biomass (straw) for energy purposes). Problemy Inżynierii Rolniczej 2010, 18, 101-110.

57. Kuś, J.; Faber, A. Alternatywne kierunki produkcji rolniczej. Studia i Raporty 2007, 7, 138-158.

58. Lach, A.; Dyjakon, A.; Noszczyk, T. Sady jabłoniowe jako lokalne źródło biomasy do ogrzewania gospodarstw domowych $\mathrm{w}$ województwie mazowieckim (Apple orchards as a source of local biomass for households heating in the Mazowieckie Voivodeship). In Rolnictwo XXI Wieku—Problemy i Wyzwania 2018; Łuczycka, D., Ed.; Idea Knowledge Future: Wroclaw, Poland, 2018; pp. 528-539.

59. GUS. Energy from Renewable Sources in 2018. Statistical Analyses. Warsaw. Available online: http://stat.gov.pl (accessed on 16 December 2020).

60. Tomczyk, M. Gospodarczo-obronne determinanty polityki energetycznej Polski (Poland's present-day energy management). Zeszyty Naukowe Wydziatu Zarzadzania i Dowodzenia Akademii Sztuki Wojennej 2017, 1, 181-195.

61. Kwaśny, J.; Banach, M.; Kowalski, Z. Przegląd Technologii Produkcji Biogazu (Technologies of biogas production from different sourcesA review). Chemia Czasopismo Techniczne Tech. Trans. Chem. 2012, 17, 83-102.

62. Damyanova, S.; Beschkov, V. Biogas as a Source of Energy and Chemicals. Biorefinery Concepts, Energy and Products. In Biorefinery Concepts; IntechOpen: London, UK, 2020. [CrossRef]

63. Pöschl, M.; Ward, S.; Owende, P. Evaluation of energy efficiency of various biogas production and utilization pathways. Appl. Energy 2010, 87, 3305-3321. [CrossRef]

64. Alluvione, F.; Moretti, B.; Sacco, D.; Grignani, C. EUE (energy use efficiency) of cropping systems for a sustainable agriculture. Energy 2011, 36, 4468-4481. [CrossRef] 
65. Jalali Sepehr, M.; Haeri, A.; Ghousi, R. A cross-country evaluation of energy efficiency from the sustainable development perspective. Int. J. Energy Sect. Manag. 2019, 13, 991-1019. [CrossRef]

66. Kaygusuz, K. Sustainable energy, environmental and agricultural policies in Turkey. Energy Convers. Manag. 2010, 51, 1075-1084. [CrossRef]

67. Wang, B.; Song, J.; Ren, J.; Li, K.; Duan, H.; Wang, X. Selecting sustainable energy conversion technologies for agricultural residues: A fuzzy AHP-VIKOR based prioritization from life cycle perspective. Resour. Conserv. Recycl. 2019, 142, 78-87. [CrossRef]

68. Borhanazad, H.; Mekhilef, S.; Saidur, R.; Boroumandjazi, G. Potential application of renewable energy for rural electrification in Malaysia. Renew. Energy 2013, 59, 210-219. [CrossRef]

69. Kumar, M. Social, Economic, and Environmental Impacts of Renewable Energy Resources. In Wind Solar Hybrid Renewable Energy System; Okedu, K.E., Ed.; IntechOpen: London, UK, 2020. [CrossRef]

70. Raza, M.Y.; Wasim, M.; Sarwar, M.S. Development of Renewable Energy Technologies in rural areas of Pakistan. Energy Sources A Recovery Util. Environ. Eff. 2019, 1-21. [CrossRef]

71. Sutherland, L.-A.; Peter, S.; Zagata, L. Conceptualising multi-regime interactions: The role of the agriculture sector in renewable energy transitions. Res. Policy 2015, 44, 1543-1554. [CrossRef]

72. Popp, J.; Lakner, Z.; Harangi-Rákos, M.; Fári, M. The effect of bioenergy expansion: Food, energy, and environment. Renew. Sustain. Energy Rev. 2014, 32, 559-578. [CrossRef]

73. Ignaciuk, A.; Vöhringer, F.; Ruijs, A.; van Ierland, E.C. Competition between biomass and food production in the presence of energy policies: A partial equilibrium analysis. Energy Policy 2006, 34, 1127-1138. [CrossRef]

74. Muscat, A.; de Olde, E.M.; de Boer, I.J.M.; Ripoll-Bosch, R. The battle for biomass: A systematic review of food-feed-fuel competition. Glob. Food Secur. 2020, 25, 100330. [CrossRef]

75. Jasiulewicz, M. Production of energy from agribiomass in Poland in the background of selected countries of the European Union. Roczniki Naukowe SERiA 2015, 8, 94-99.

76. Owczuk, M.; Wardzińska, D.; Zamojska-Jaroszewicz, A.; Matuszewska, A. Wykorzystanie odpadów biodegradowalnych do produkcji biogazu jako alternatywnego źródła energii odnawialnej. Studia Ecologiae et Bioethicae UKSW 2013, 11, 133-144. [CrossRef]

77. Nevzorova, T.; Kutcherov, V. Barriers to the wider implementation of biogas as a source of energy: A state-of-the-art review. Energy Strategy Rev. 2019, 26, 100414. [CrossRef]

78. Bartoszewicz-Burczy, H. Biomass potential and its energy utilization in the Central European countries. Energetyka 2012, 12, 860-866.

79. Portal na Rzeczy Czystej Energii i Klimatu. Leonardo Energy. Polska nie Osiagnie celu OZE. Available online: https://leonardoenergy.pl/ (accessed on 18 December 2020).

80. Zhu, D.; Mortazavi, S.M.; Maleki, A.; Aslani, A.; Yousefi, H. Analysis of the robustness of energy supply in Japan: Role of renewable energy. Energy Rep. 2020, 6, 378-391. [CrossRef]

81. Harmsen, R.; Wesselink, B.; Eichhammer, W.; Worrell, E. The unrecognized contribution of renewable energy to europe's energy savings target. Energy Policy 2011, 39, 3425-3433. [CrossRef]

82. Garrett-Peltier, H. Green versus brown: Comparing the employment impacts of energy efficiency, renewable energy, and fossil fuels using an input-output model. Econ. Model. 2016, 61, 439-447. [CrossRef]

83. Janik, W.; Kaproń, H.; Paździor, A. Uwarunkowania rozwoju produkcji energii elektrycznej na bazie źródeł odnawialnych (Conditions for development of electricity production based on renewable energy sources). Rynek Energii 2018, 2, 1-11.

84. Radziszewska-Zielina, E.; Rumin, R. Analysis of The Profitability of Investment In Renewable Energy Sources On The Example of A Semi-Detached House. In Proceedings of the First International Conference on the Sustainable Energy and Environment Development, Krakow, Poland, 17-19 May 2016; pp. 1-4. [CrossRef]

85. Jedlińska, K.; Olkuski, T. The decision-making process in the EU in the field of energy policy. Energy Policy J. 2019, 22, 5-18. [CrossRef] 